\title{
Reduction in size of prolactin-secreting tumours in men treated with pergolide
}

\author{
PAT KENDALL-TAYLOR，K HALL，D G JOHNSTON， R W G PRESCOTT
}

\begin{abstract}
The effect of pergolide mesylate was studied in two previously untreated men with large prolactinomas and exceptionally high prolactin concentrations. The study was designed to determine whether pergolide would be effective in alleviating symptoms, correcting hormonal abnormalities and shrinking the tumour. Starting with $50 \mu \mathrm{g}$ daily the dose of pergolide was slowly increased over 10 weeks to $1 \mathrm{mg}$ once daily, when repeat assessment was performed. Both patients reported complete relief of symptoms, with no side effects. Serum prolactin concentration was suppressed to normal in both subjects, and evidence to suggest tumour shrinkage was observed.

Pergolide appears to be effective treatment for men with large prolactinomas.
\end{abstract}

\section{Introduction}

Pergolide mesylate is a new potent synthetic ergoline that has long-lasting dopamine-receptor agonist activity. It differs from other dopamine agonists previously used to treat hyperprolactinaemia in its greater potency and longer duration of action in vivo ${ }^{12}$; also in that it is effective at receptors linked to dopamine-sensitive adenylate cyclase. ${ }^{3}$

Pergolide lowers serum prolactin concentrations in normal subjects $^{4}$ and in patients with hyperprolactinaemia. ${ }^{5}$ Other dopamine agonists have been reported to induce tumour regression in patients with prolactin-secreting pituitary tumours, ${ }^{6} 7$ and pergolide clearly has potential therapeutic value

\footnotetext{
Department of Medicine, Royal Victoria Infirmary, Newcastle upon Tyne NE1 4LP

PAT KENDALL-TAYLOR, MD, FRCP, consultant physician and senior lecturer in medicine

D G JOHNSTON, PHD, MRCP, Wellcome senior clinical research fellow $R$ W G PRESCOTT, MB, MRCP, research registrar

Department of Neuroradiology, Newcastle General Hospital, Newcastle upon Tyne

K HALL, FRCR, consultant neuroradiologist
}

in the treatment of these patients. We therefore assessed the effect of this drug in patients with pituitary tumours and evaluated its effect on tumour size.

\section{Patients and methods}

CASE 1

The patient was a man aged 53 , who complained of stuffiness at the back of the nose, aching behind the nose, and bloodstained nasal discharge when bending; he denied headaches and impotence but had noticed diminishing libido. He had no children. He was a normally androgenised man with no gynaecomastia or galactorrhoea; weight was $92 \mathrm{~kg}$ and blood pressure $150 / 80 \mathrm{~mm} \mathrm{Hg}$. Visual fields were full. He had taken no medication and had no medical history.

Mean basal serum prolactin concentration was grossly raised at $132400 \mathrm{mU} / 1$; thyroid function and urea and electrolyte concentrations were normal. There was a poor prolactin response to thyrotrophin-releasing hormone and no prolactin response to insulin hypoglycaemia or domperidone; the table summarises results of other hormone studies.

The sella turcica was appreciably enlarged with evidence of tumour extending down into the sphenoidal sinus, which was confirmed by computed tomography. No suprasellar extension of tumour was seen on scanning, and a metrizamide cisternogram showed a small degree of empty sella.

\section{CASE 2}

The patient, a man aged 47 , gave a 15 -year history of tiredness, lack of stamina, headaches, loss of body hair, and waning libido and impotence, the latter two having become absolute in the past three years. His youngest child was 17 years old. There was no other history, and he had received no medication. On examination body hair was scanty and of female distribution but facial hair was present; he had gynaecomastia but no galactorrhoea; the testes were normal; weight was $76.5 \mathrm{~kg}$ and blood pressure $120 / 80 \mathrm{~mm} \mathrm{Hg}$. Visual fields were full.

Mean basal serum prolactin concentration was considerably raised at $17300 \mathrm{mU} / 1$; thyroid function and urea and electrolyte concentrations were normal. Serum prolactin concentration failed to increase after thyrotrophin-releasing hormone, insulin, or domperidone was given.

The sella turcica was enlarged, though slightly less so than in case 1 . Computed tomography suggested, and metrizamide cisterno- 
graphy confirmed, a slight suprasellar extension of the intrasellar tumour (figure (left)).

\section{METHODS}

Assay methods-Concentrations of prolactin, thyroid-stimulating hormone, luteinising hormone, follicle-stimulating hormone, growth hormone, and testosterone were measured by radioimmunoassay. The prolactin assay was a double antibody method using MRC $71 / 222$ as standard. The normal range for men lies below $400 \mathrm{mU} / 1$.

Treatment and reassessment-Pergolide mesylate was given in a single daily dose with the evening meal starting at $50 \mu \mathrm{g}$ and increasing to $1 \mathrm{mg}$. Both patients gave informed consent and were warned of possible side effects. Patients were seen at two- or three-week intervals, when liver function tests and electrocardiography were performed. Full clinical biochemical and radiological assessment was repeated when the patients were stabilised on a dose of $1 \mathrm{mg}$ daily: in case 1 this was 14 weeks and in case 210 weeks after the start of treatment.

\section{Results}

CASE 1

Within two weeks of the start of treatment, at a dose of $200 \mu \mathrm{g}$ pergolide daily, there was a considerable improvement in symptoms and prolactin concentration fell to $5000 \mathrm{mU} / \mathrm{l}$. Symptoms had disappeared completely by 10 weeks: prolactin concentration con-

Biochemical effects of pergolide mesylate (1 mg daily) in two men with prolactinomas

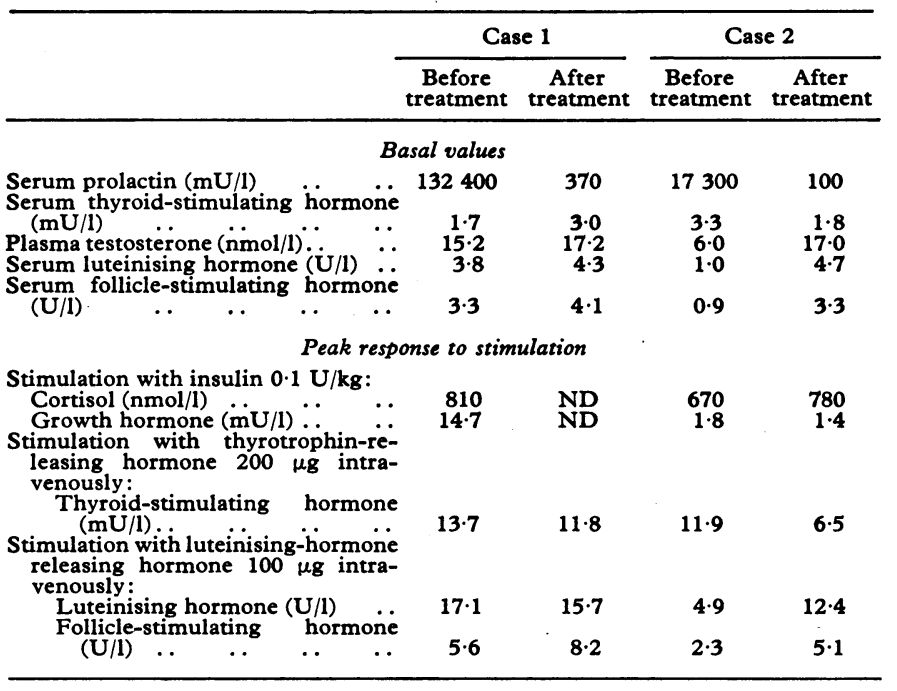

$\mathrm{ND}=$ Not done.

Conversion: $S I$ to traditional units-Testosterone: $1 \mathrm{nmol} / 1 \approx 0.3 \mathrm{ng} / \mathrm{ml}$. Cortisol: $1 \mathrm{nmol} / 1 \approx 36 \mathrm{ng} / 100 \mathrm{ml}$

tinued to fall, reaching normal by 18 weeks $(370 \mathrm{mU} / \mathrm{l})$, and at six months was $130 \mathrm{mU} / \mathrm{l}$. The patient reported no adverse symptoms. Results of liver function tests and electrocardiography were still normal at six months.

After 14 weeks' treatment a repeat skull $x$-ray film and computed tomography showed no change. Repeat metrizamide cisternography, however, showed a deepening of the empty sella, probably indicating some tumour shrinkage.

CASE 2

This patient reported a considerable increase in energy, lifting of depression, and loss of headaches by three weeks, when prolactin had fallen into the normal range at $255 \mathrm{mU} / 1$. Potency and libido were fully restored. Reassessment was at 10 weeks, when the prolactin concentration was $100 \mathrm{mU} / \mathrm{l}$ and testosterone concentration normal at $17 \mathrm{nmol} / 1(4.9 \mathrm{ng} / \mathrm{ml}$; table). He noticed slight nausea on occasions within one hour of taking pergolide, and the dose was subsequently reduced to $500 \mu \mathrm{g}$ daily with no loss of efficacy. Results of liver tests and electrocardiography remained normal throughout. During the trial he developed an epididymal cyst.

A repeat skull $x$-ray film and computed tomography showed no definite change after 10 weeks of treatment. Metrizamide cisternography, however, showed that the suprasellar extension had gone and that the sella was partially empty (figure (right)), indicating shrinkage of the tumour.
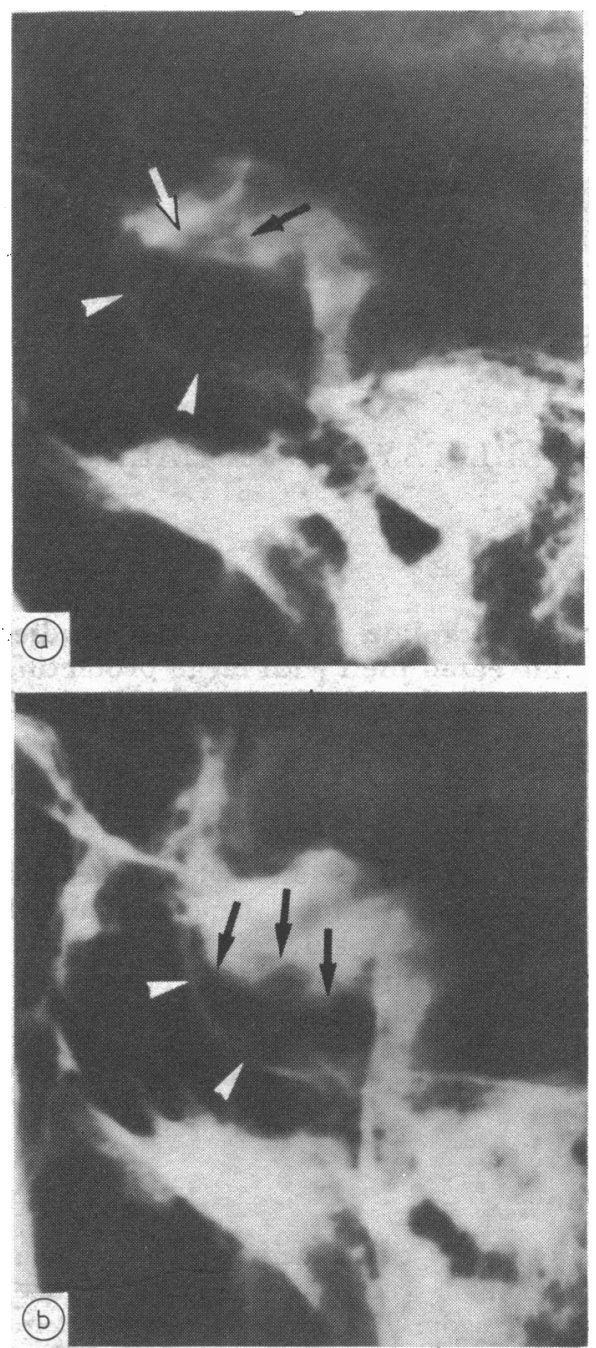

Case 2. Metrizamide cisternograms showing (a) small suprasella extension of pituitary tumour and (b) new, empty sella 10 weeks after the start of treatment. (Floor of sella turcica shown by white arrowheads.)

\section{Discussion}

The response of these two patients with exceptionally high circulating prolactin concentrations to pergolide shows that the drug is effective in relieving symptoms, inhibiting secretion of prolactin, and inducing tumour regression. Previous studies in man have reported lowering of prolactin concentrations in normal subjects, ${ }^{4}$ patients with Parkinson's disease, ${ }^{8}$ and patients with hyperprolactinaemia ${ }^{5}$; only one patient reported on previously had a large pituitary tumour, and $150 \mu \mathrm{g}$ pergolide did not satisfactorily reduce the serum prolactin concentration. ${ }^{5}$ A higher dose (1 $\mathrm{mg}$ ) was used in the patients reported in this study.

A major finding of recent years has been that drug treatment 
with bromocriptine may lead to shrinkage of pituitary tumours ${ }^{6}$ and may be particularly effective in men. ${ }^{9}$ This is important in patients with macroadenomas as other forms of treatment such as surgery or irradiation may be unnecessary. The present study has shown a similar action of pergolide, with both patients showing tumour regression and the sella becoming partially empty. Pergolide may therefore also be useful as sole treatment in certain patients with large prolactin-secreting tumours. This drug seems certain to find a place, though whether it will offer any real advantage over bromocriptine has yet to be established.

We thank Mr David Mathias and Dr E W Barnes for referring the patients; Dr A Glynn and Dr J Scotton of Eli Lilly, London; Mrs L Brown, Dr D Cook, and Dr M Watson for hormone assays; and the Cancer Research Campaign for financial support.

\section{References}

${ }^{1}$ Lemberger L, Crabtree RE. Pharmacologic effects in man of a potent long-acting dopamine receptor agonist. Science 1979;205:1151-2.
2 Grossman A, Yeo T, Delitala G, Hathnay NR, Besser GM. Two new dopamine agonists that are long acting in vivo but short acting in vitro. Clin Endocrinol 1980;13:595-9.

${ }^{3}$ Goldstein M, Lieberman A, Lew JY, Asano T, Rosenfeld MR, Makman MH. Interaction of pergolide with central dopaminergic receptors. Proc Natl Acad Sci 1980;77:3725-8.

4 Lemberger L, Crabtree R, Callaghan JT. Pergolide, a potent longacting dopamine receptor agonist. Clin Pharmacol Ther 1980;27:642-51.

${ }^{5}$ Franks S, Horrocks PM, Lynch SS, Butt WR, London DR. Treatment of hyperprolactinaemia with pergolide mesylate: acute effects and preliminary evaluation of long term treatment. Lancet 1981 ;ii:659-61.

- George SR, Burrow GN, Zinman B, Ezrin C. Regression of pituitary tumours, a possible effect of bromoergocriptine. Am $\mathcal{F}$ Med 1979;66: 697-702.

${ }^{7}$ McGregor AM, Scanlon MF, Hall R, Hall K. Effect of bromocriptine on pituitary tumour size. Br Med 7 1979;ii:700-3.

${ }^{8}$ Kleinberg DL, Lieberman A, Todd J, Greising J, Neophytides A, Kudersmith $M$. Pergolide mesylate: a potent day-long inhibitor of prolactin in rhesus monkeys and patients with Parkinson's disease. f Clin Endocrinol Metab 1980;51:152-4.

${ }^{9}$ Prescott RWG, Johnston DG, Kendall-Taylor P, et al. Hyperprolactinaemia in men-response to bromocriptine therapy. Lancet $1982 ; \mathrm{i}: 245-8$.

(Accepted 4 fune 1982)

\title{
Septicaemia due to Yersinia enterocolitica after oral overdoses of iron
}

\author{
KJETIL MELBY，SOFIE SL ØRDAHL，TORE JARL GUTTEBERG，SVEIN ARNE NORDB $\varnothing$
}

\begin{abstract}
Septicaemia occurred after accidental oral overdoses of iron in two previously healthy children. Yersinia enterocolitica serotype 0:3 was recovered from blood and stool cultures in both patients.

Enhanced growth of $\mathbf{Y}$ enterocolitica in the intestine combined with damage of intestinal mucosa may have been of major importance for the development of generalised infection in these cases. Iron and the iron chelating agent desferrioxamine may possibly have a pathogenetic role in such circumstances.
\end{abstract}

\section{Introduction}

Iron is essential for the growth of all micro-organisms. ${ }^{1}$ Several in-vitro and in-vivo studies have shown enhanced microbial multiplication in response to increased availability of iron. ${ }^{1}$ In small children infection caused by Yersinia enterocolitica usually presents as acute self-limiting gastroenteritis. ${ }^{2}$ In all age groups septicaemia due to $Y$ enterocolitica is rare and occurs primarily in patients whose host defence is compromised by underlying illness or by immunosuppressive treatment. ${ }^{3}$ Most reported cases have been in patients suffering from disease

\section{University Hospital, 9012 Troms $₫$, Norway}

KJETIL MELBY, MD, consultant, department of medical microbiology TORE JARL GUTTEBERG, MD, senior registrar, department of paediatrics

Ullevål University Hospital, Oslo 1, Norway

SOFIE SLØRDAHL, MD, senior house officer, department of paediatrics SVEIN ARNE NORDB $\varnothing, M D$, senior house officer, department of medical microbiology implicating iron overload, as in cirrhosis, blood dyscrasias, and siderosis. $^{3}$

We report two cases of $Y$ enterocolitica septicaemia in previously healthy children after excess oral intake of iron, showing a possible pathogenetic role for iron and the iron cheiating agent desferrioxamine.

\section{Case reports}

CASE 1

A previously healthy 21-month-old girl was admitted to hospital with a two-day history of slight diarrhoea. Two hours before admission she had ingested 30 capsules of ferrocarbonate $(90 \mathrm{mg}$ iron/ $\mathrm{kg}$ body weight).

On admission she seemed in perfect health and physical examination was normal. She was treated with washouts of $0.9 \%$ sodium chloride solutions and intragastric instillation of $5 \mathrm{~g}$ desferrioxamine (Desferal) and sodium bicarbonate. Because of vomiting this treatment was repeated once and then $1 \mathrm{~g}$ desferrioxamine given intramuscularly. The initial serum iron concentration of $22 \mathrm{mmol} / \mathrm{l}(122.9 \mathrm{mg} / 100 \mathrm{ml})$ dropped to $4 \mathrm{mmol} / 1(22 \cdot 3 \mathrm{mg} / 100 \mathrm{ml})$ after 26 hours, and transferrin saturation never exceeded $40 \%$.

Twenty-four hours after ingesting the iron she developed fever up to $40^{\circ} \mathrm{C}$ and her general condition deteriorated. Septicaemia was suspected, and she received ampicillin $200 \mathrm{mg} / \mathrm{kg}$ for five days and tobramycin $6 \mathrm{mg} / \mathrm{kg}$ body weight daily for 10 days. Her condition improved but one week after admission she developed a red, tender, swollen, and immobilised left knee. Her arthritis subsided after two to three days.

In three blood cultures obtained before antibiotic treatment $Y$ enterocolitica serogroup 3 was isolated. On cultivating faeces obtained the day after the excess iron intake the same organism was recovered in heavy growth. Cultivation was done by inoculating faecal specimens in glucose broth for five days at $4^{\circ} \mathrm{C}$ followed by subculturing on lactose-bromothymol blue and lactose-sucrose-urea plates. Specific antibodies to $Y$ enterocolitica increased from 40 on day 5 to 320 on day 15 and subsequently decreased to 80 on day 38 . Cultures of synovial fluid from the left knee on day 10 showed no growth of $Y$ enterocolitica. She recovered fully with no sequelae. 